\title{
A new species of Leinendera Carrera, 1945 \\ (Diptera, Asilidae, Asilinae) from Brazil
}

\author{
Rodrigo Vieira ${ }^{1,2}$ \\ ${ }^{1}$ Programa de Pós-graduação em Entomologia - CPEN, Instituto Nacional de Pesquisas da Amazônia - \\ INPA, Campus II, CEP 69060-000, Manaus, AM, Brazil \\ ${ }^{2}$ Corresponding author: Rodrigo Vieira, e-mail: rodrigo08vieira@gmail.com
}

VIEIRA, R. A new species of Leinendera Carrera, 1945 (Diptera, Asilidae, Asilinae) from Brazil. Biota Neotrop. 12(3): http://www.biotaneotropica.org.br/v12n3/en/abstract?short-communication+bn00712032012

Abstract: The second species of Neotropical genus Leinendera Carrera, 1945, Leinendera nigra sp. n. is described from Rio de Janeiro state, Brazil. The habitus, wing, male terminalia of L. nigra sp. n. are described and illustrated. The diagnosis and illustrations of type-species Leinendera rubra Carrera, 1945 are provided.

Keywords: Asilus-group, neotropical, taxonomy.

VIEIRA, R. Uma nova espécie de Leinendera Carrera, 1945 (Diptera, Asilidae, Asilinae) do Brasil. Biota Neotrop. 12(3): http://www.biotaneotropica.org.br/v12n3/pt/abstract?short-communication+bn00712032012

Resumo: A segunda espécie do gênero Neotropical Leinendera Carrera, 1945, Leinendera nigra sp. n. é descrita para o Rio de Janeiro, Brasil. São fornecidas descrições e ilustrações do hábito, asa, estruturas da terminália masculina de L. nigra sp. n. Além disso, são fornecidos uma diagnose e ilustrações da espécie-tipo, Leinendera rubra Carrera, 1945.

Palavras-chave: grupo-Asilus, região neotropical, taxonomia. 


\section{Introducion}

Leinendera Carrera, 1945 is characterized by the presence of apical scutellar setae; wing with spot (dense microtriquia) on third apical; tergites with lateral marginal macrosetae; epandrium more or less conical, with dense setae and ovipositor short, more or less conical, without spines (Carrera 1945).

Leinendera is a monotypic genus and Carrera (1945) described the type-species, Leinendera rubra based on holotype (Rio de Janeiro city, Brazil) and 3 paratypes, 1 male and 2 females (Rio de Janeiro city and São Paulo (Juquiá, Santo André (Paranapiacaba), Brazil).

Carrera (1945) also remarked on the similarity between Leinendera and Glaphyropyga Schiner (Schiner 1866), and provided illustrations of postpedicel, thorax in dorsal view, wing, mid right leg, male terminalia in ventral view and lateral view, and ovipositor in lateral view of Leinendera rubra. Posteriorly, Artigas \& CarreraSuárez (2011) described and illustrated the female terminalia of L. rubra.

In this work it is described and illustrated a new species for Leinendera from Rio de Janeiro state, Brazil and it is provided illustrations and diagnosis of L. rubra.

\section{Materials and Methods}

The present study examined specimens housed in Instituto Oswaldo Cruz (IOC), Rio de Janeiro, Rio de Janeiro, Brazil.

Morphological terminology follows Cumming and Wood (2009). Detached wings were mounted on microslides in Canada balsam. After gluing a microslide to the edge of a piece of thick paper, the specimen was pinned to the paper so that the slide was directly next to the specimen pin. Dissected terminalia were placed in a $10 \% \mathrm{KOH}$ solution at $40{ }^{\circ} \mathrm{C}$ for 8 hours, washed in water, treated with $10 \%$ acetic acid, and subsequently examined in concavity slides in glycerin. After examination and illustration, the detached parts were placed in microvials with glycerin and pinned with their respective specimens.

The label data is cited in full, with the original spellings, punctuations, and dates. Information presented within square brackets is complementary data not included on the labels. For corrections of localities are used parentheses. Data for the same specimen but from different labels are separated by slashes (/).

\section{Results}

\section{Leinendera Carrera, 1945}

Leinendera Carrera, 1945: 184. Type-species, Leinendera rubra Carrera (orig. des.).

\section{Leinendera rubra Carrera, 1945}

Leinendera rubra Carrera, 1945: 185, Figures 13, 19, 22-28; Carrera (Carrera 1958): 150; Hull (Hull 1962) (2): 512, Figures 379, 797, 1400, 1409, 2419-2420; Martin \& Papavero (Martin \& Papavero 1970): 83 (catalogue); Papavero (Papavero 2009): 8; Artigas \& Carrera-Suárez 2011: 6, Figures 4a, c.

Diagnosis. Body slender (Figure 1a); lower facial margin without a black projection (Figures 1b, c); 1 supra-alar setae; base of r4 slightly narrow (Figure 1d); epandrium rounded in lateral view (Figure 1e); epandrium with apex curved inwards (Figure 1f); gonocoxite subquadrangular with a median keel turned backward (Figures 1g, 2b); hypandrium with setae arranged horizontally (Figure 2a); subepandrial sclerite simple, without projections (Figure 2c); gonostyle with basal external margin subtriangular (Figure 2d); aedeagus wide in lateral view with apex curved for up (Figure 2e); tergite IX $+\mathrm{X}$ not divided medially (Figure 2f); female sternite VIII proximally platelike, hypogynial valves forming keel distally (Figure 2g).

Material examined. [BRASIL], [Rio de Janeiro], Itatiaia,

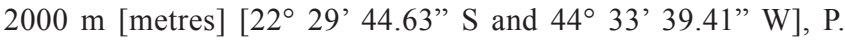
Wichart [collector], ii.1941/Leinendera rubra M.[essias] Carrera det.[erminante] [19]56 (1 male IOC); [BRASIL], [Virgínia?] [Minas Gerais?], F.[azenda?] d.[os?] Campos, 1500 m [etres], S. M./Leinendera rubra Carrera/Coleção J. F. Zikan (1 female IOC).

\section{Leinendera nigra Vieira sp. $n$.}

Diagnosis. Body slender (Figure 3a); lower facial margin with a black projection (Figures 3b, d); 1 supra-alar macroseta and 1 seta; base of $\mathrm{r} 4$ narrow (Figure $3 \mathrm{f}$ ); epandrium with apex straight (Figure 4a); epandrium subretangular in lateral view with a short projection at apex (Figure 4c); hypandrium with a tuft of short yellow setae on the middle (Figure 4d); gonostyle curved, tapered until apex (Figure 4e); gonocoxite subquadrangular with a projection on external margin (Figure 4e, f); aedeagus strongly curved for down (Figure 4g); subepandrial sclerite with a basal plate (Figure 4h).

Description male holotype. Body: slender (Figure 3a). Head (Figures 3b, d). Scape and pedicel yellow (Figures 3b, d), postpedicel brown (Figure 3e); postpedicel 14 times the length of first element of stylus and second element of stylus 3 times the length of the first element (Figure 3e); vertex golden tomentose; ocellar tubercle dark brown; 2 brown short ocellar setae; face and frons golden tomentose (Figure 3c); face moderately narrow (Figure 3c); lower facial margin with a black projection (Figures $3 \mathrm{~b}, \mathrm{~d}$ ); mystacal macrosetae yellow, except brown setae on lateral margin and portion superior of facial gibbosity (Figure 3c); occiput gray tomentose; occipital setae yellowish; 3 light brown postocular macrosetae; palpus brown with brown setae; apical setae of palpus longer than others; proboscis black laterally and ventrally, brown dorsally with yellowish ventral setae; labial setae yellowish.

Thorax (Figure 3b) Antepronotum and postpronotum brown, golden and silver tomentose; mesonotum brown with two golden longitudinal stripe; humeral spot golden tomentose; lateral border of mesonotum golden tomentose in dorsal view; posterior portion of mesonotum, postalar spot and scutellum silver tomentose; scutellum with impressed rim; pleuron with two golden inclined stripe interspersed with a brown stripe extending to fore and mid coxa (Figure 3b). Chaetotaxy: 2 brown notopleural macrosetae; 1 brown supra-alar macroseta and 1 brown seta; 1-2 brown postalar macrosetae; 4 brown presutural dorsocentral setae and 4 pairs of brown dorsocentral macrosetae; 2 brown apical scutellar setae; discal scutellar setae brown; anatergal setae yellowish; katatergal setae yellowish; posterior meron + metanepisternum with 2 yellow macrosetae.

Wing (Figure 3f). Basal 2/3 yellow, 1/3 apical and ventral margin of cual with dense microtrichia; $R_{2+3}$ strongly sinuous at level of $\mathrm{R}_{4}$ and $\mathrm{R}_{5}$ bifurcation; cell $\mathrm{r} 4$ narrow; no costal dilation; $\mathrm{R}_{4}$ and $\mathrm{R}_{5}$ bifurcation placed beyond discal cell apex; crossvein $\mathrm{r}-\mathrm{m}$ situated before middle of discal cell; microtrichia on posterior margin arranged in two divergent planes; halter pale yellow mixed with black. Stem of halter yellow with brown knob.

Legs (Figure 3a). All legs narrow. Legs yellowish to light brown. Chaetotaxy: hind trochanter with yellow setae; fore femora with 4 yellow setae ventrally; middle femora with 1 yellow seta anteriorly, 3 yellowish setae anteroventrally, 2 yellowish setae posteroventrally and 1 posterior preapical seta; hind femora with 3 yellowish anterior setae, 1 yellowish posterior seta, a group of disorganized rows of short yellow setae posteriorly, 3 yellowish setae posteroventrally; 
Vieira, R.
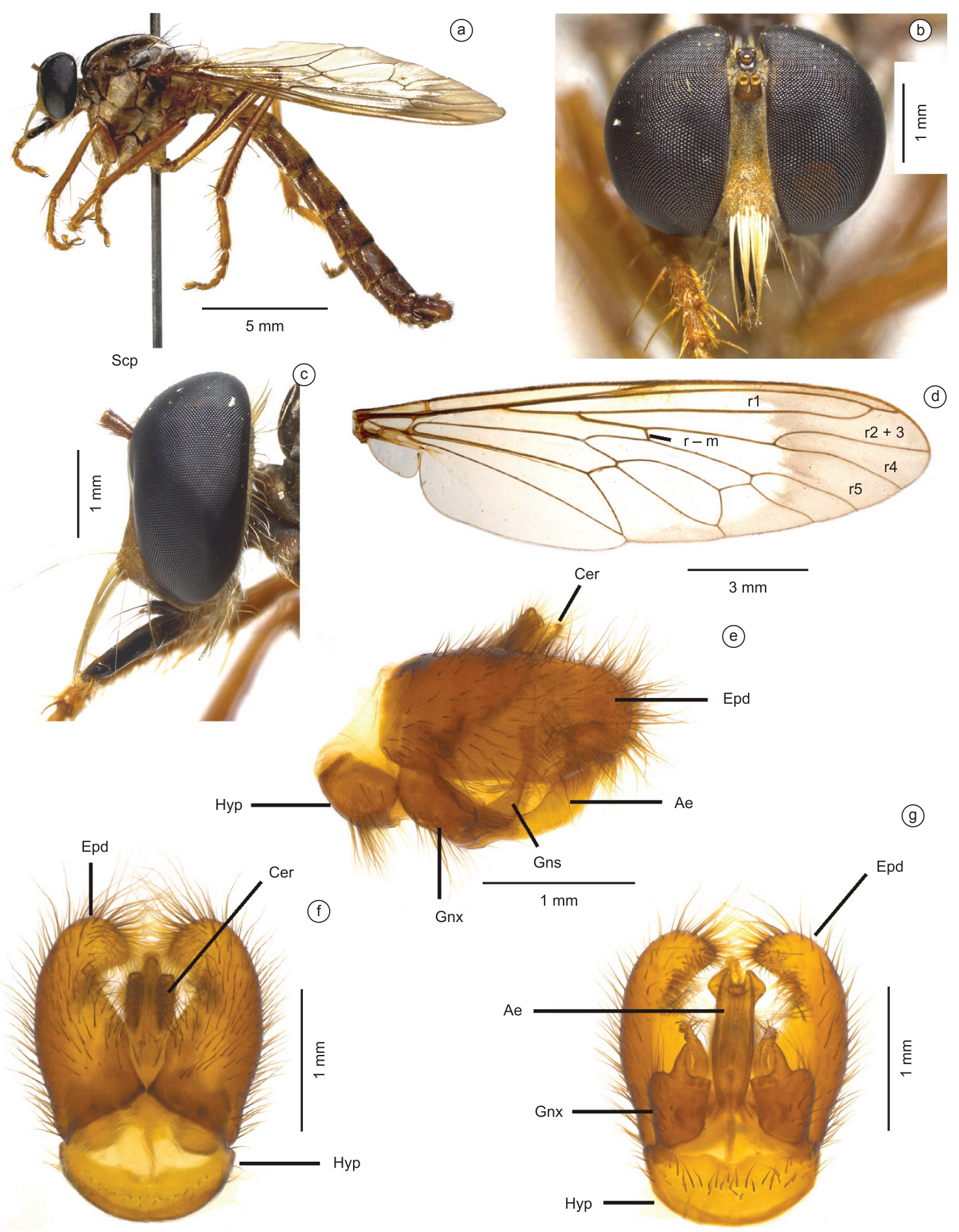

Figure 1. Leinendera rubra Carrera, 1945, male. a) Habitus, lateral view; b) Head, frontal view; c) Head, lateral view; d) Wing; e) Male terminalia, lateral view; f) Male terminalia, dorsal view; g) Male terminalia, ventral view. Abbreviations: Cer: cercus; Epd: epandrium; Gnx: gonocoxite; Gns: gonostylus; Hyp: hypandrium; Ae: Aedeagus; Scp: Scape.

fore tibiae with 3 long yellow macrosetae laterally; middle tibiae with 3 long yellow macrosetae anteroventrally, 1 long yellow macroseta posteroventrally, 1 basal yellow seta posteriorly; hind tibiae with 3 yellow setae anterodorsally; all macrosetae and setae of tarsomeres yellow.

Abdomen. Brown. In lateral view each tergite possess a golden triangular spot medially. Tergites with yellow lateral marginal macrosetae.
Terminalia (Figures 4a, h). Epandrium dorsally brown to reddish, yellowish ventrally; others structures of terminalia light brown; epandrium wide in dorsal view (Figure 4a); epandrium subretangular in lateral view with a short projection at apex (Figure 4c); epandrium in ventral view with slight hollow subapically and yellow setae at apex (Figure 4b); hypandrium rectangular with a tuft of short yellow setae on the middle (Figure 4d); gonocoxal apodeme narrow (Figure 4e); gonostyle curved, tapered until apex (Figure 4e); gonocoxite 


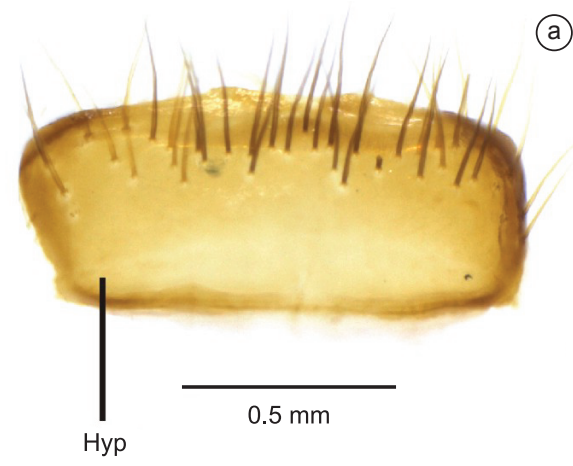

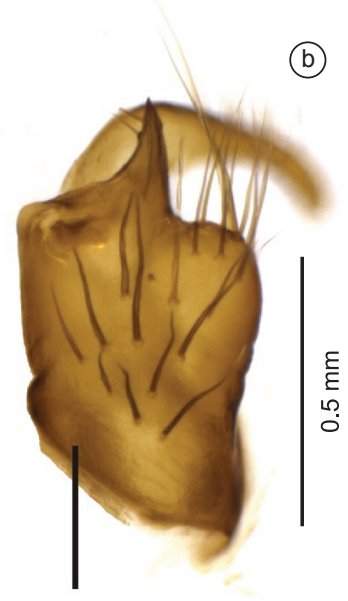

Gnx

(b)


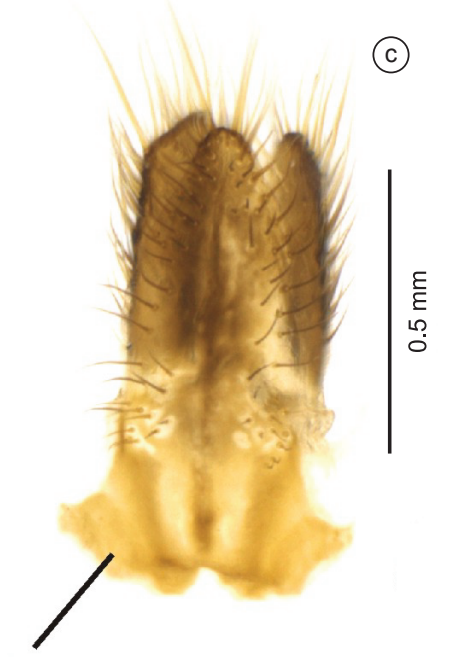

Sub scl

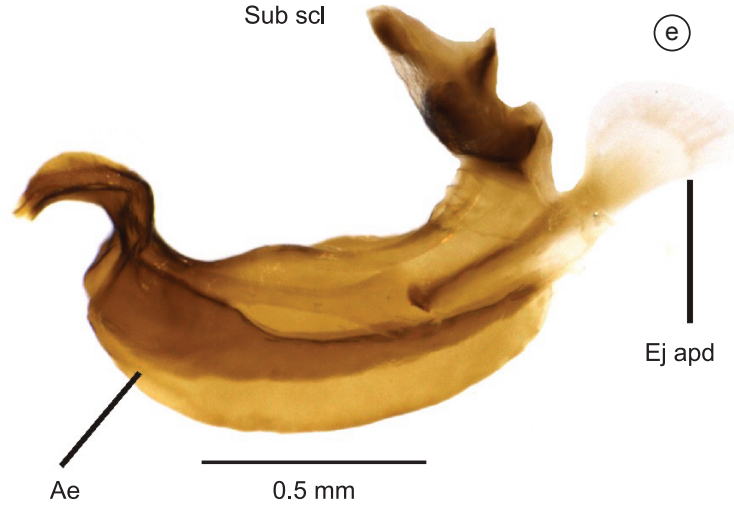

(e)

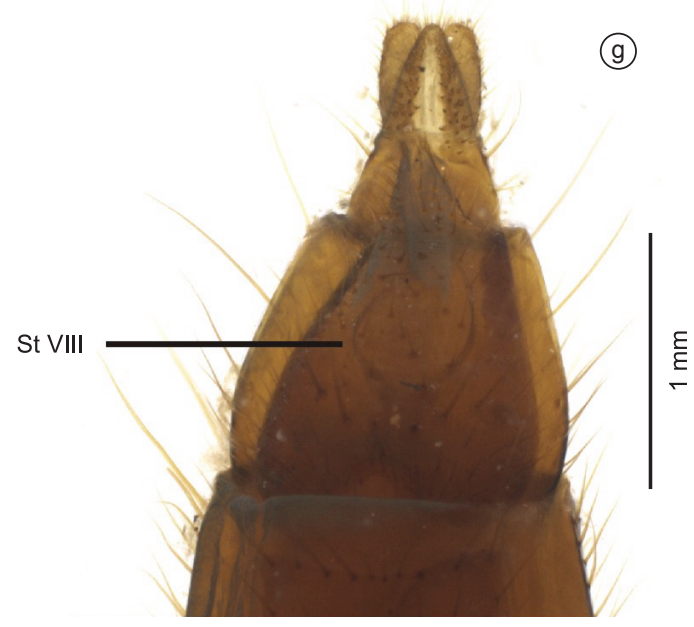

Figure 2. Leinendera rubra Carrera, 1945, male and female. a) Hypandrium; b) Gonocoxite; c) Subepandrial sclerite; d) Gonostylus; e) Aedeagus and ejaculatory apodeme; f) Ovopositor, dorsal view; g) Ovopositor, ventral view. Abbreviations: Ej apd: ejaculatory apodeme; Gnx: gonocoxite; Gns: gonostylus; Gx apd: gonocoxal apodeme; Hyp: hypandrium; Ae: Aedeagus; St VIII: Sternite VIII; Sub scl: Subepandrial sclerite; TVIII: Tergite VIII; T IX + X: Tergite IX + X.

subquadrangular with a projection on external margin (Figure 4f); aedeagus with only a prong, strongly curved for down (Figure 4g); ejaculatory apodeme wide in lateral view (Figure 4g); subepandrial sclerite with a basal plate (Figure 4h).
Female. Unknown.

Etymology. From latin nigra = black. It makes allusion to the lower facial margin with a black projection.

Size. Body length $16.6 \mathrm{~mm}$; Wing length $12.1 \mathrm{~mm}$. 
Vieira, R.

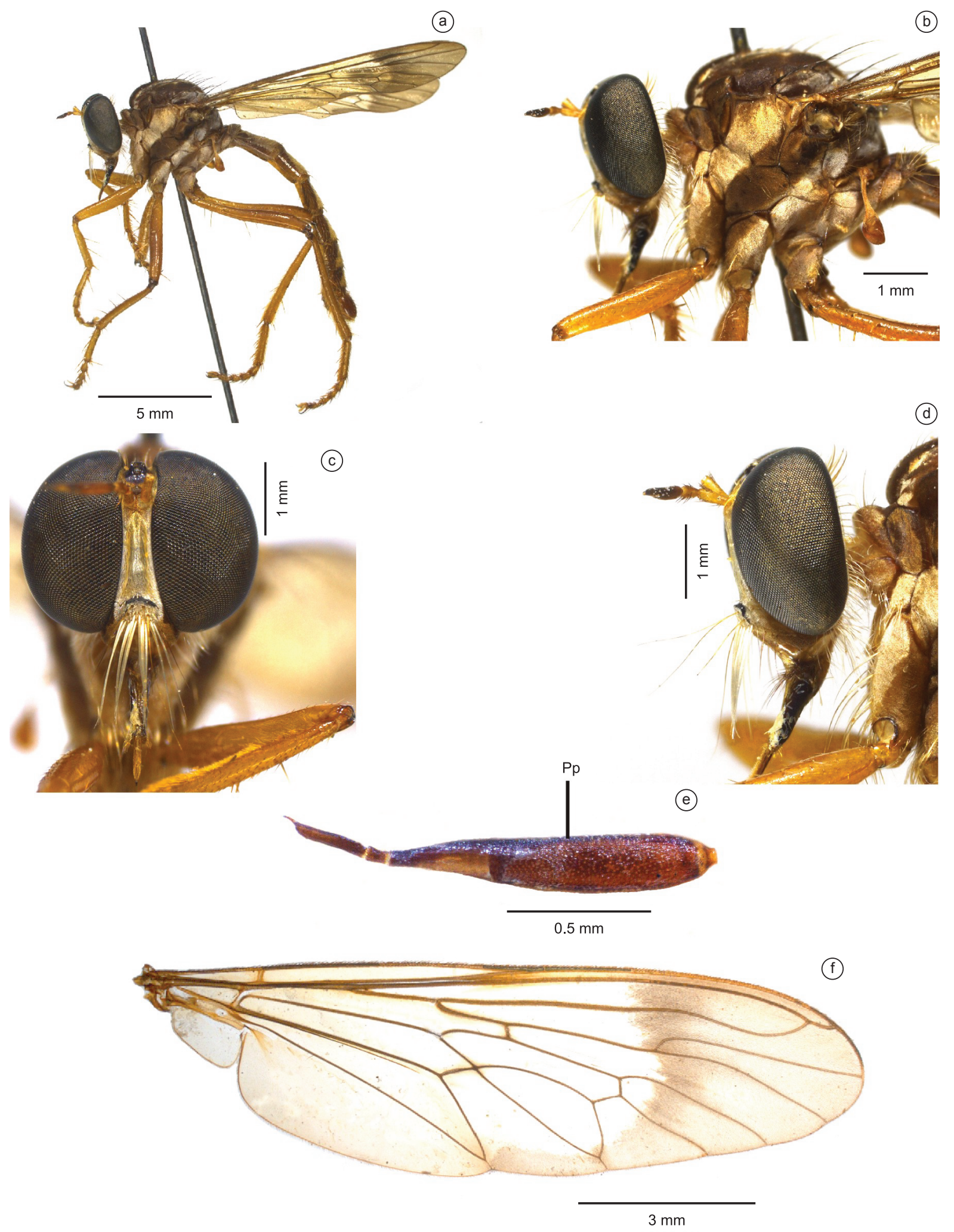

Figure 3. Leinendera nigra Vieira sp. nov. male. a) Habitus, lateral view; b) Head and thorax, lateral view; c) Head, frontal view; d) Head, lateral view; e) Postpedicel, lateral view; f) Wing. Abbreviations: Pp.

Holotype condition. Left pedicel and postpedicel glued on the label; right stylus lost; mid tibia and tarsomeres lost. Detached wing mounted on microslides, terminalia placed in microvial with glycerin and pinned along with the specimen.
Type material. Holotype male: [BRASIL], D.[istrito] Federal \{Rio de Janeiro\}, Trapicheiro, [Rio de Janeiro], 22.v.1944, [22 ${ }^{\circ} 54^{\prime}$ 30.33 " S and $43^{\circ} 12^{\prime} 50.95$ " W], Milton Valle [collector]/Holótipo Leinendera nigra Vieira (IOC).

Distribution. Brazil: Rio de Janeiro state, São Paulo state. 

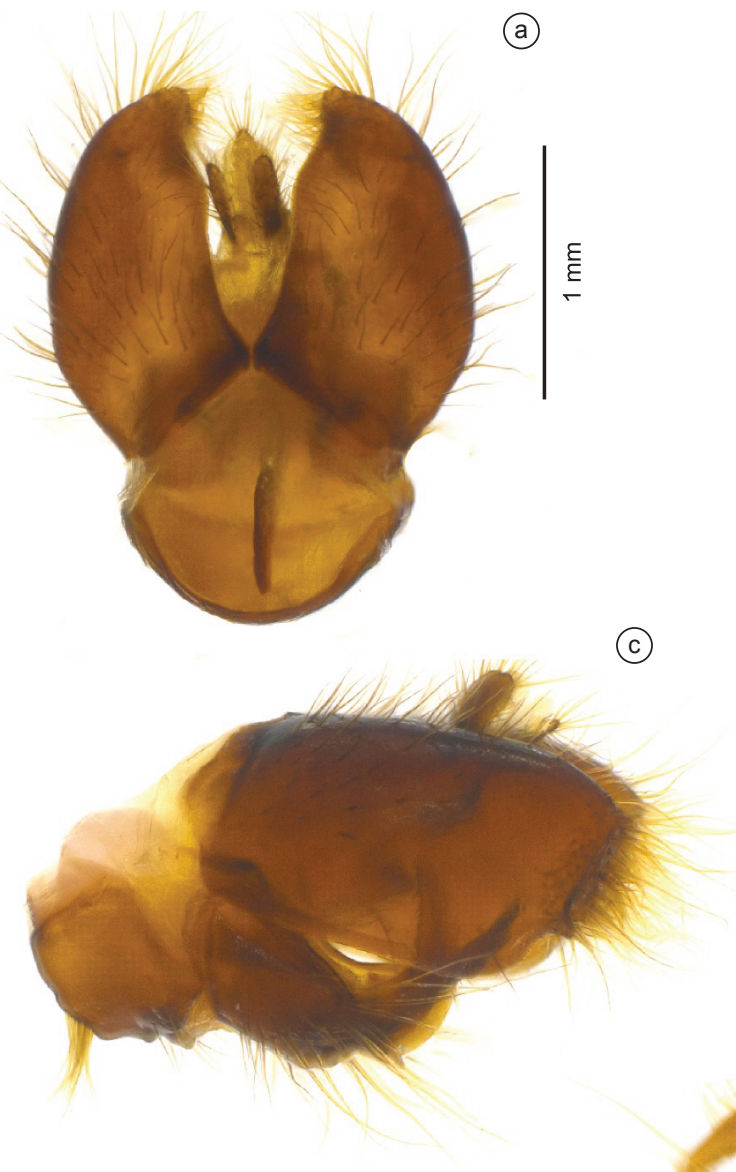

$1 \mathrm{~mm}$

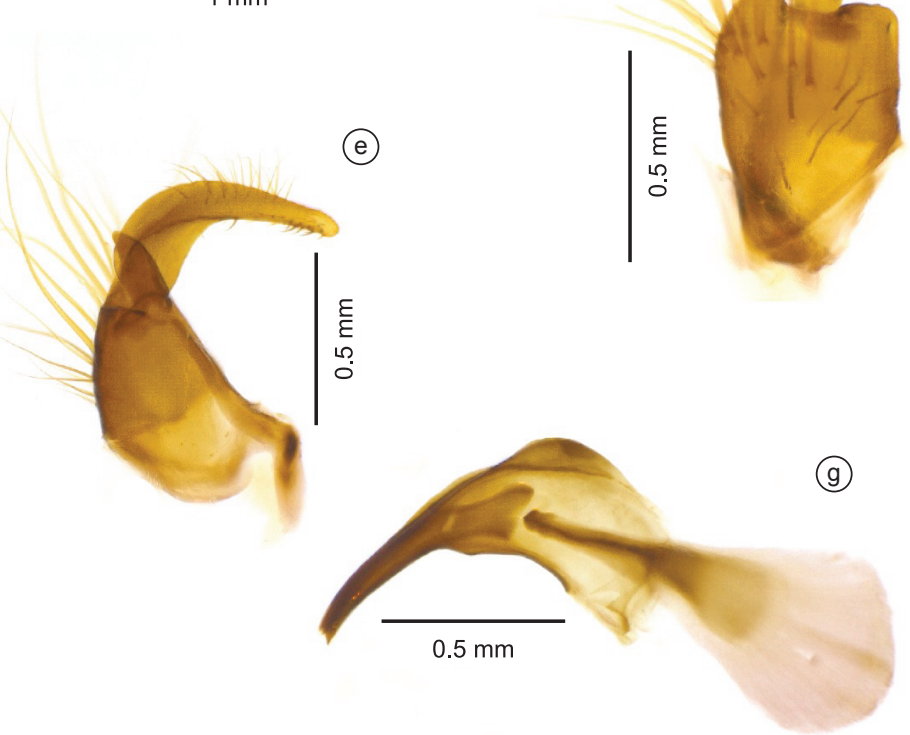

(b)

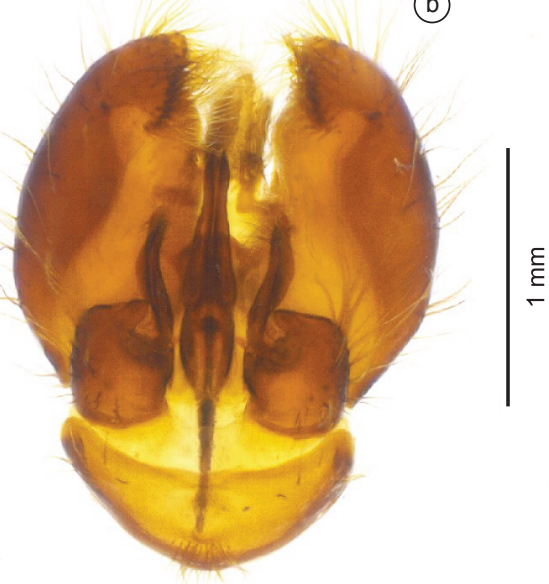

(d)

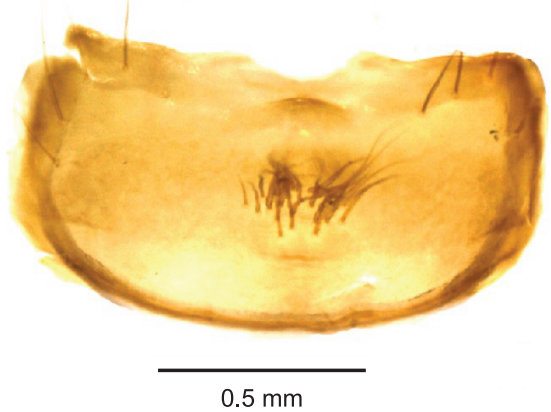

(†)

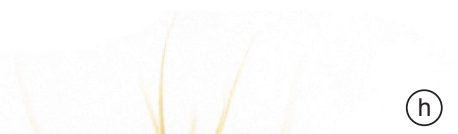

(n)

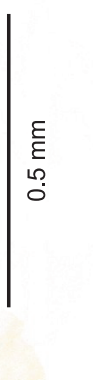

Figure 4. Leinendera nigra Vieira sp. nov. male. a) Male terminalia, dorsal view; b) Male terminalia, ventral view; c) Male terminalia, lateral view; d) Hypandrium; e) Gonostylus; f) Gonocoxite; g) Aedeagus and ejaculatory apodeme; h) Subepandrial sclerite.

\section{Discussion}

L. nigra sp. n. is externally similar to L. rubra. Both species possess stripes on pleuron (Figures 1a, $3 \mathrm{a}, \mathrm{b}$ ) and $1 / 3$ apical of wing with dense microtrichia (Figures 1d, 3f). However, L. nigra sp. n. can be separated from L. rubra by characters presented in the diagnoses of both species and terminalia.

\section{Acknowledgements}

To CNPq for the fellowships that have allowed me to complete this work. To Fundação de Amparo à Pesquisa do Estado do Amazonas (FAPEAM) by the financial support to the Project PRONEX, Edital (016/2006, Proc. 1437/2007). To Dr. Márcio Félix and Danielle Cerri 
Vieira, R.

from Instituto Oswaldo Cruz who permitted the study of Leinendera specimens.

\section{References}

ARTIGAS, J.N. \& CARRERA-SUÁREZ, L.E. 2011. Previously NonIllustrated Genitalia of Some Known Asilinae Species (Insecta: Diptera: Asilidae). J. Entomol. Res. Soc. 13:1-14.

CARRERA, M. 1945. Estudo sobre os gêneros Glaphyropyga e Senoprosopis com descrição de novo gênero e novas espécies. Pap. Avulsos Dep. Zool. 5:175-192.

CARRERA, M. 1958. Dípteros de Boracéia. I. Asilidae. Pap. Avulsos Dep. Zool. 13:141-154.
CUMMING, J.M. \& WOOD, D.M. 2009. Adult morphology and terminology. In Manual of Central American Diptera. (B.V. Brown, A. Borkent, J.M. Cumming, D.M. Wood, N.E. Woodley \& M. Zumbado, eds.). NRC Research Press, Ottawa, p.9-50.

HULL, F.M. 1962. Robber Flies of the World: The Genera of the Family Asilidae. Bull. United States Nat. Mus., Part 2. 224:431-906.

MARTIN, C.H. \& PAPAVERO, N. 1970. A catalogue of the Diptera of the Americas south of the United States, Family Asilidae. Bol. Mus. Zool. USP 35:1-139.

PAPAVERO, N. 2009. Catalogue of Neotropical Diptera. Asilidae. Neotrop. Diptera 17:1-178.

SCHINER, J.R. 1866. Die Wiedemannischen Asiliden, interpretiert und in die seither errichteten neuen Gattungen eingereiht. Verh. Zool.-Bot. Ges. Wien, 16:649-722. 